\title{
Optimization of the Implementation Design of Distributed Energy Resources in Micro-Grids
}

INGENIERÍA ELÉCTRICA

\section{Optimización del Diseño de Implementación de Recursos Energéticos Distribuidos en Micro-Redes}

\author{
Willyam M. Viñán ${ }^{1 \S}$ (i), Alex R. Guamán' ${ }^{10}$ \\ ${ }^{1}$ Universidad Politécnica Salesiana, Departamento de Posgrados, Quito, Ecuador \\ \$wvinanr@est.ups.edu.ec,aguamana4@est.ups.edu.ec
}

Recibido: 21 de julio de 2020 - Aceptado: 1 de marzo de 2021

\begin{abstract}
This article develops a study about the energy resources available in microgrids, extracting and analyzing data form satellite databases, in order to apply it to the technologies available. On the other hand, a demand estimation is carried out based on measurements, and finally an optimization is performed to determine the most economically profitable option with the correspondent graphs and analysis.
\end{abstract}

Keywords: Demand Estimation, Distributed Generation, Energy Resources, Micro grid.

\section{Resumen}

Este artículo desarrolla un estudio acerca de los recursos energéticos disponibles en micro-redes, extrayendo y analizando bases de datos satelitales, con el propósito de aplicarlas en las tecnologías disponibles. Por otro lado, se efectúa la estimación de la demanda usando como base las mediciones de consumo, y finalmente, mediante optimización se determina la opción más económicamente rentable con los correspondientes gráficos y análisis.

Palabras clave: Estimación de la Demanda, Generaciòn Distribuida, Micro Red, Recursos Energéticos

\section{Introduction}

Smart grid capabilities provide people enough tools to develop the way they interact with energy in terms they never imagined before because the lack of technology ${ }^{(1)}$, however, nowadays with the progressive advent of the communication era, the internet of things ${ }^{(2)}$, smart devices and more, all kind of networks have been formed throughout society, not only in technical terms but also on sociological and collaborative aspects. 
Electricity is the main promotor of this leap forward in pro of development, and then, it is fair that people now, who are facing the actual circumstances that are reshaping the way we live, take advantage of the resources which are close to our place ${ }^{(3)}$. These resources can benefit people in such a manner that they can create a community more sustainable and eager to explore and enjoy what nature has provide next to them ${ }^{(4)}$.

Incorrect investments in generation technology can result in a loss of money over time and even in the final abandon of the project and returning to use the conventional energy, for this reason it is extremely important to be well informed and carry out a formal study with technical and economic variables in order to success in the implementation, maintenance and manage of the implementation of distributed energy resources in micro-grids.

Many times, people don't get interest in the resources they have at hand, not knowing all the potential that can be achieved just by exploiting them in a responsible and sustainable manner ${ }^{(5)}$. Now through this investigation, it is proved the importance of the well administered resources taking the right decisions about the implementation of distributed energy exploitation (6), all of this achieved thanks to the real data of cost of energy, amount of energy resources locally available and technology required which has been entered into the optimization software Homer Energy PRO, whose outputs have been carefully analyzed, presented and concluded.

\section{Methodology}

\subsection{Electricity Demand from residentials}

Electricity demand from a residence is something which could be shaped up to a point, and it is time for people to start getting discipline and education about modifying their electricity consumption patterns ${ }^{(7)}$, because nobody knows when energy will be on scarcity, or people should depend on rules for its usage, among others. In any case, a good tool to empower people about the energy administration is to involve them in the whole process of modernization of the grid ${ }^{(8)}$.

The integration of distributed resources into the grid can provide many benefits to the users in terms of participation of the responsible use of energy ${ }^{(9)}$, and also benefits to the grid itself as reliability, voltage and frequency regulation, and count on more active participants. For these reasons, one of the first steps is evaluating the resources available in the current area to be exploited in a sustainable way ${ }^{(10)}$.

Participants of the smart grid get active when they experience the continuous and monthly money savings thanks to the implementation of the new technologies, consequently, they get interested in increasing their knowledge in distributed energy resources and the additional importance of a culture of energy savings in order to keep reducing their expenses through their active participation.

Sun, the almighty source of power, a nuclear reactor located 8 light-minutes distance from Earth ${ }^{(11)}$, is the source of a huge part of the energy available on our planet, then photovoltaic energy and wind energy are two key aspects to be considered about the resources to be taken advantage of ${ }^{(12)}$.

Top of Chimborazo mount, the furthest point on earth measuring from the right center of the core of the planet is one of the giants who guard a valley full of resources in which it erects The Very Noble and Very Loyal City of Saint Peter of Riobamba ${ }^{(13)}$, which is going to be the specific case in which the electricity micro grid will be measured and developed. The coordinates to be used are: $01^{\circ} 38^{\prime} 59,27^{\prime}$ S $78^{\circ} 40^{\prime} 10,51^{\prime}$ W.

A study of the demand pattern has been carried out monitoring the electricity consumption of a typical family of three members on a routine day, getting as a result the daily power curve showed in Figure 1. 
Through the usage of the data showed in this curve, it is possible to analyze the peak and valley hours in demand which must be meet by the energy supply, and figure out the best complements to the local resources to be used in the smart micro-grid in development ${ }^{(14)}$. In this terms, it is evident that as a regular residential load, the demand pattern has the main peak in the night hours, which is not going to be supplied by the solar energy and it is going to be difficult for the wind too, for that reason it is mandatory to consider the usage of batteries to storage energy to be used in this period of time mentioned ${ }^{(15)}$

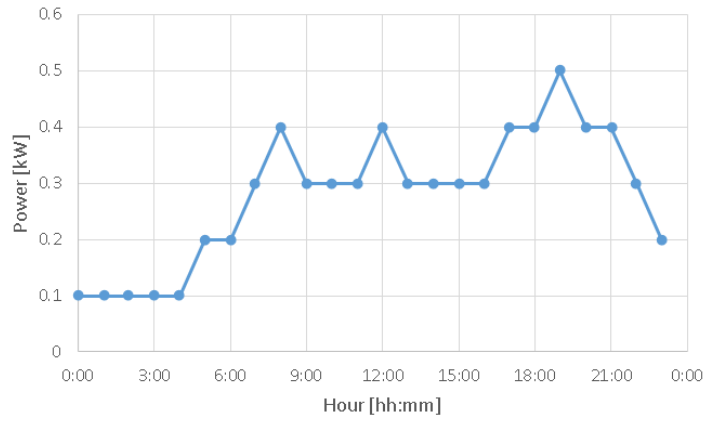

Figure 1. Daily Power Curve

\subsection{Distributed Energy Resources}

The solar resource data is presented in Figure 2, this energy is important because of the all-year permanent solar radiation the zone receives, and taking advantage of enough space to install solar photovoltaic panels ${ }^{(16)}$.

Another resource evaluated is wind ${ }^{(17)}$, whose availability is shown in Figure 3. Making use of the databases available, it is evident that the wind resource is not what could be expected to take advantage of this type of energy, however this distributed resource has been taken into account for the optimization and for corresponding evaluation of possibilities ${ }^{(18)}$.

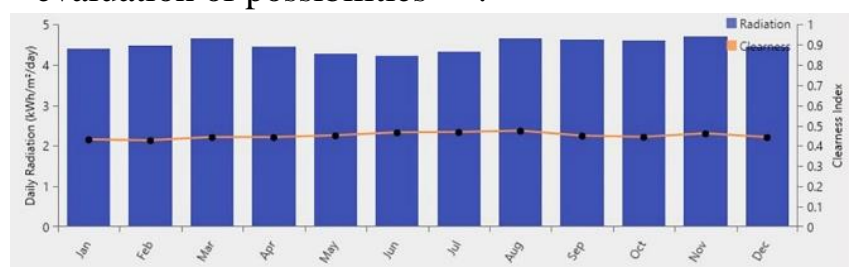

Figure 2. Monthly Solar Radiation Level

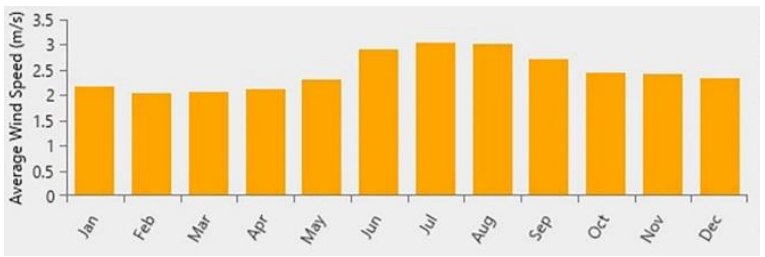

Figure 3. Monthly Average Wind Speed

Sets of batteries are necessary to accomplish a better performance of the distributed resources, and they are considered for the optimization done (19). At the same time, due to the fact that electric and electronic equipment runs from $\mathrm{AC}$ power input, it is necessary to include an inverter for transforming DC power form lines connected to the batteries and solar panels into AC power to be used by the equipment.

\subsection{Micro Grid Simulation}

For the development of the Micro-Grid with penetration of renewable energy for the residential home proposed as the study case, it is used the software Homer Energy PRO ${ }^{(20)}$. The Micro-architecture is presented in Figure 4, remarking that it is a connected microgrid to feed the load characterized on Figure 1 with photovoltaic panels and a wind turbine as renewable generation, a bank of batteries as energy storage and an inverter to change DC to $\mathrm{AC}$ current. The characteristics of the elements are presented on

Table 1.

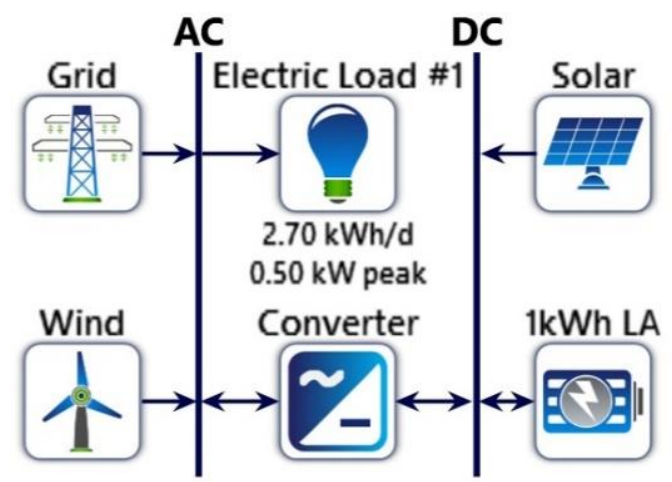


Figure 4. Micro-Grid Architecture

Table 1. Micro-Grid Elements

\begin{tabular}{lcc}
\hline Component & Power[kW] & $\begin{array}{c}\text { Cost Equipment } \\
\text { [USD] }\end{array}$ \\
\hline Photovoltaic & Power Supply \\
Panel & 0.5 & 500.00 \\
Wind Turbine & 0.4 & 500.00 \\
Battery & 1 & 300.00 \\
Storage & Cost of Energy [USD] \\
Grid & \multicolumn{2}{c}{0.09} \\
Converter & Control Equipment \\
\hline
\end{tabular}

\section{Results and Discussion}

\subsection{Optimization Results}

Homer Energy allows to analyze all possible networks derived from the architecture showed in Figure 4, the results of the optimization process are presented in Table 2. As we can see, photovoltaic resource is better than wind resource, due to the fact that the average wind speed is not good enough. Energy storage provides stability to the micro-grid specially in this case in which renewable resources are stochastic. However, the levelized cost of energy (LCOE) and the initial capital are raised.

When the network operates with all its resources, we obtain the best percentage of renewable energy participation with an increase of the cost of energy and the whole capital needed. On the other hand, the network with the best LCOE only needs photovoltaic source without energy storage.

Figure 5 and Figure 6 present the cash flow projection over 25 years, and as we can see the best opportunity to get a profit return is the case of solar generation without energy storage.

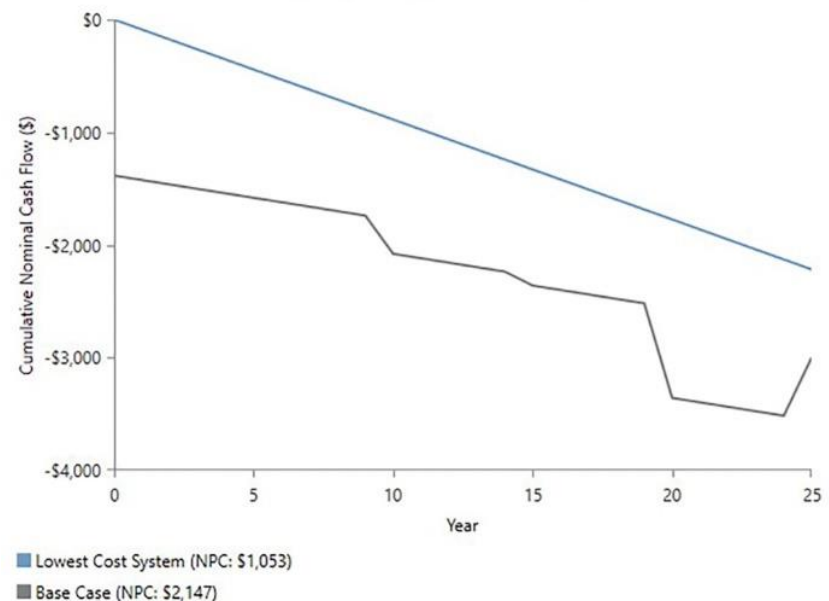

Table 2. Optimization Results

\begin{tabular}{|c|c|c|c|c|c|c|c|c|}
\hline \multirow[b]{2}{*}{ Solar } & \multicolumn{2}{|c|}{ Power Supply } & \multirow[b]{2}{*}{ Grid } & \multicolumn{5}{|c|}{ Cost } \\
\hline & Wind & Battery & & $\begin{array}{c}\text { Converter } \\
(\mathbf{k W})\end{array}$ & $\begin{array}{l}\text { LCOE } \\
\text { (USD) }\end{array}$ & $\begin{array}{c}\text { Operating } \\
\text { cost (USD/yr) }\end{array}$ & $\begin{array}{c}\text { Initial capital } \\
\text { (USD) }\end{array}$ & $\begin{array}{l}\text { Renewable } \\
\text { Energy (\%) }\end{array}$ \\
\hline \multirow{3}{*}{$\mathrm{x}$} & & & $\mathrm{x}$ & & 0.090 & 88.69 & 0 & 0 \\
\hline & & & $\mathrm{x}$ & 0.28125 & 0.084 & 51.96 & 584.31 & 48.60 \\
\hline & $\mathrm{x}$ & & $\mathrm{x}$ & & 0.107 & 67.73 & 500 & 40.92 \\
\hline \multirow[t]{2}{*}{$\mathrm{x}$} & $\mathrm{x}$ & & $\mathrm{x}$ & 0.28125 & 0.092 & 36.81 & 1084.37 & 72.39 \\
\hline & & $\mathrm{x}$ & $\mathrm{x}$ & 0.001563 & 0.143 & 116.14 & 300.46 & 0 \\
\hline \multirow[t]{2}{*}{$\mathrm{x}$} & & $\mathrm{x}$ & $\mathrm{x}$ & 0.28125 & 0.128 & 79.40 & 884.37 & 48.60 \\
\hline & $\mathrm{x}$ & $\mathrm{x}$ & $\mathrm{x}$ & 0.001563 & 0.158 & 95.18 & 800.46 & 40.91 \\
\hline $\mathrm{x}$ & $\mathrm{x}$ & $\mathrm{x}$ & $\mathrm{x}$ & 0.28125 & 0.130 & 64.25 & 1384.31 & 72.39 \\
\hline
\end{tabular}


Figure 5. Full Arquitecture Cash Flow Projection

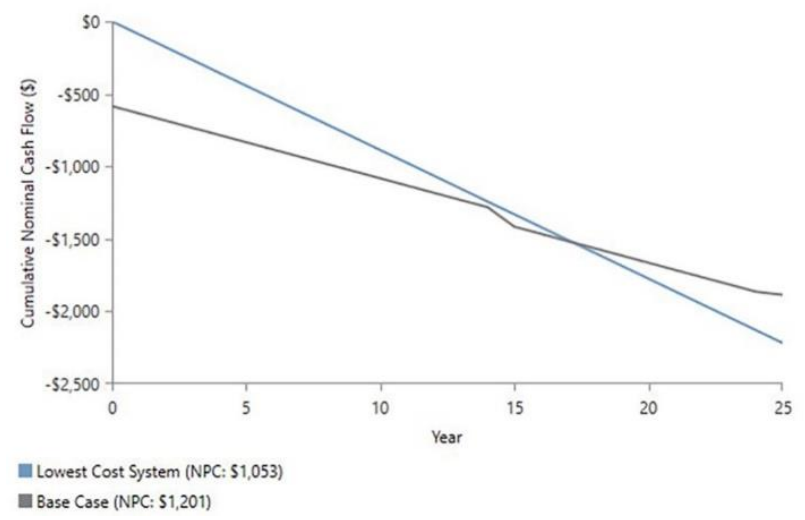

Figure 6. Cash Flow Projection for the case of solar generation without energy storage

The amount of energy produced by the energy resources is presented in Figure 7 and Figure 8. Figure 7 shows that the grid electricity consumption is considerably reduced. Wind energy is quite variable with the best production registered in August. Solar energy represents the best resource. Figure 8 presents an increase of solar participation. However, without wind energy the rest of the energy is taken from the grid.

Referring to Figure 1, it can be said that daily demand has a peak during the early night hours, there is a medium consumption during the day hours, and demand goes really low during late night hours. With the advent of solar energy, demand during day hours will be served in conjunction with the grid energy when necessary, and then just the night hours will be the only ones served exclusively by the grid.

\section{Conclusions}

The importance of the empowerment of people about energy issues is the main contribution a micro grid can provide to the community, including the fact that users get a full consciousness of the horizon of the energy generation and its responsible and sustainable usage, due to the fact that when people start knowing that local resources can be used for own consumption, a new way of thinking is achieved in pro of nature.

In the case analyzed in this research, it has been showed that some of the energies initially considered for the optimization, as the case of wind, at last it resulted that it is not profitable and technically possible its exploitation, taking into account that these results are attached to the actual technology and its prices, characteristics, efficiencies and more.

The importance of the analysis done, and the process of this research constitutes a beacon to point in the direction of development, and it is necessary to get deeper in related investigations of the topic of micro-grids in order to get the directive lines and evolution the cases can be attached to, due to the improvements, politics and

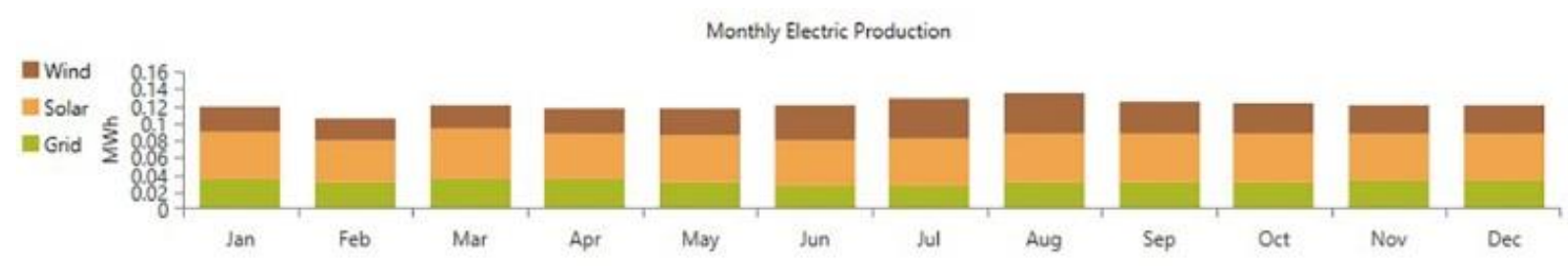

Figure 7. Full architecture energy production

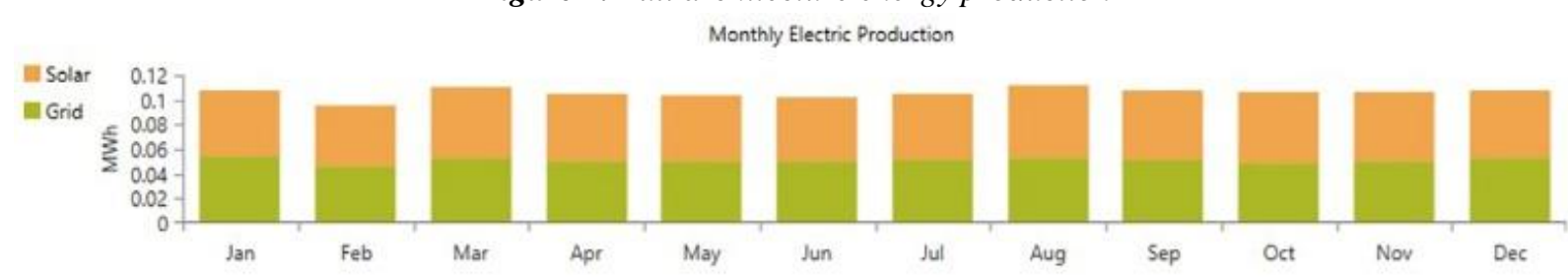

Figure 8. Energy production for the case of solar generation without energy storage 
developments in terms of distributed energy resources usage.

\section{Funding Statement}

The author(s) received no specific funding for this work.

\section{References}

(1) Uribe-Perez N, Angulo I, De La Vega D, Arrinda A, Arzuaga T, Marron L, et al. TCP/IP capabilities over NB-PLC for Smart Grid applications: Field validation. 2017 IEEE Int Symp Power Line Commun its Appl ISPLC 2017. 2017;1-5. https://doi.org/10.1109/ISPLC.2017.7897 118.

(2) Yu L, Nazir B, Wang Y. Intelligent power monitoring of building equipment based on Internet of Things technology. Comput Commun. 2020;157:76-84. https://doi.org/10.1016/j.comcom.2020.0 4.016 .

(3) Strezoski L, Stefani I, Brbaklic B. Active Management of Distribution Systems with High Penetration of Distributed Energy Resources. In: EUROCON 2019 - 18th Int Conf Smart Technol. 2019;1-5. https://doi.org/10.1109/EUROCON.2019. 8861748 .

(4) Laschefski K. Conflicting urban and rural territorial livelihood metabolisms: The "explosion" of the "sustainable" urbanindustrial pulp complex in Bahia - Brazil. Sustain Cities Soc. 2019;45:159-71. https://doi.org/10.1016/j.scs.2018.11.030

(5) Viñán WM, García EM. Review of Electricity Markets for Smart Nano-Grids. Ing Y Compet. 2019;21(2):1-10. https://doi.org/10.25100/iyc.v21i2.7462.

(6) Piedrahita-Velásquez CA, Ciro-Velásquez HJ, Arango-Tobón JC. Mejoramiento De
La Respuesta Transitoria Y La Eficiencia Energética De Un Sistema De Refrigeración Con Compresor De Velocidad Variable Usando Metodología Anti-Windup. Ing Y Compet. 2018;20(2):9-18. https://doi.org/10.25100/iyc.v20i2.6752.

(7) Wen L, Zhou K, Yang S. A shape-based clustering method for pattern recognition of residential electricity consumption. J Clean Prod. 2019;212:475-88.: https://doi.org/10.1016/j.jclepro.2018.12. 067.

(8) Sarkis J, Cordeiro JJ. Ecological modernization in the electrical utility industry: An application of a bads-goods DEA model of ecological and technical efficiency. Eur J Oper Res. 2012;219(2):386-95.

http://dx.doi.org/10.1016/j.ejor.2011.09.0 33.

(9) Mohani SSUH, Awan AL, Akhtar S, Ansari H. Smart grid system. In: Proc 2016 SAI Comput Conf SAI 2016. 2016;1278-85. https://doi.org/10.1109/SAI.2016.755614 4.

(10) Vargas-Pineda OI, Trujillo-González JM, Torres-Mora MA. Huella hídrica: Una herramienta eficaz para el desafío de la sostenibilidad del agua. Ing Y Compet. 2020;22(1):1-12. https://doi.org/10.25100/iyc.v22i1.8429.

(11) Gutiérrez M, Masip M. The Sun at TeV energies: Gammas, neutrons, neutrinos and a cosmic ray shadow. Astropart Phys. 2020;119:1-4.

https://doi.org/10.1016/j.astropartphys.20 20.102440 .

(12) Haviv S, Revivo N, Kruger N, Rotschild C. Luminescent solar power - Quantum separation between free-energy and heat 
for cost-effective base-load solar energy generation. In: 2019 Conf Lasers ElectroOptics Eur Eur Quantum Electron Conf CLEO/Europe-EQEC. 2019;1. https://doi.org/10.1109/CLEOEEQEC.2019.8872478.

(13) Jamieson RW, Sayre MB. Barley and identity in the Spanish colonial Audiencia of Quito: Archaeobotany of the 18th century San Blas neighborhood in Riobamba. J Anthropol Archaeol. 2010;29(2):208-18.

http://dx.doi.org/10.1016/j.jaa.2010.02.00 3.

(14) Dönük A, El-Aff I, Yilmaz M. Metering and data processing in a micro-scale area for smart grid applications. In: 4th Int Istanbul Smart Grid Congr Fair, ICSG. 2016.

https://doi.org/10.1109/SGCF.2016.7492 432.

(15) Siddique R, Raza S, Mannan A, Khalil L, Alwaz N, Riaz M. A modified NSGA approach for optimal sizing and allocation of distributed resources and battery energy storage system in distribution network. Mater Today Proc. 2020; In press. https://doi.org/10.1016/j.matpr.2020.05.6 69.

(16) Maia ASC, Culhari E de A, Fonsêca V de FC, Milan HFM, Gebremedhin KG. Photovoltaic panels as shading resources for livestock. J Clean Prod. 2020;258(11):120551.

https://doi.org/10.1016/j.jclepro.2020.120 551.

(17) Ren G, Wan J, Liu J, Yu D. Characterization of wind resource in China from a new perspective. Energy. 2019;167:994-1010. https://doi.org/10.1016/j.energy.2018.11. 032.

(18) Dinh HT, Yun J, Kim DM, Lee KH, Kim D. A Home Energy Management System with Renewable Energy and Energy Storage Utilizing Main Grid and Electricity Selling. IEEE Access. 2020;8:49436-50.

https://doi.org/10.1109/ACCESS.2020.29 79189.

(19) Garcia E, Isaac I. Demand response systems for integrating energy storage batteries for residential users. In: 2016 IEEE Ecuador Tech Chapters Meet ETCM. $2016 . \quad$ pp. 1-6. https://doi.org/10.1109/ETCM.2016.7750 818.

(20) HOMER Energy LLC. HOMER Pro Version 3.7 User Manual. HOMER Energy. 2016;(August):416. Disponible en:

http://www.homerenergy.com/pdf/HOM ERHelpManual.pdf. 